\title{
Coping Self-Talk Training Using Blended Learning to Develop Counselors' Competence
}

\author{
Adi Atmoko* \\ Guidance and Counseling Department \\ Faculty of Education, \\ Universitas Negeri Malang \\ Malang, Indonesia \\ adi.atmoko.fip@um.ac.id* \\ Irene Maya Simon \\ Guidance and Counseling Department \\ Faculty of Education, \\ Universitas Negeri Malang \\ Malang, Indonesia \\ irene.maya.fip@um.ac.id
}

\author{
Henny Indreswari \\ Guidance and Counseling Department \\ Faculty of Education, \\ Universitas Negeri Malang \\ Malang, Indonesia \\ henny.indreswari.fip@um.ac.id \\ Nugraheni Warih Utami \\ Guidance and Counseling Department \\ Faculty of Education, Universitas Negeri Malang \\ Malang, Indonesia \\ nugraheni.warih.fip@um.ac.id
}

\begin{abstract}
This research aims to develop counselors' competence through a coping self-talk training with blended learning-based media (face-to-face, offline, and online). This experimental research was conducted on 25 counselors from 5 cities in Indonesia. Data were analyzed using a non-parametric statistical hypothesis test (Wilcoxon test). The research results showed that counselors' competence development through a coping self-talk training with a blended learning method was significantly able to improve coping self-talk skills in counseling. Therefore, participants can improve their professionalism in performing counseling services. The changes were in the form of a decrease in negative self-talk and an increase in counselors' coping self-talk.
\end{abstract}

Keywords—coping self-talk, school counselors, blended learning

\section{INTRODUCTION}

The complexity of the problems experienced by students demands professional competence from a counselor. Professional competences include personal competence, social competence, pedagogical competence, and professional competence which can be obtained by counselors through participation in expertise programs. Reference [1] states that counselors can enhance their professional competence by following an ongoing expertise program. The improvement of counselors' expertise is expected to be able to help students in solving problems faced at school. This expectation is inversely proportional to the challenges faced by counselors recently, i.e. the limitations in improving counselors' knowledge and skills to apply counseling techniques to counselees (students) [2]. This limitation influences counselors' skills to succeed in the counseling process. Whereas, in fact, counselors' skills are extremely needed in conducting counseling services, especially their skills in controlling their own thoughts.

The skills of controlling one's thoughts are called mind skills. Reference [3] states that counselors need these skills to initiate feelings, physical reactions, communication, as well as conducive measure to promote welfare within counselees. In mind skill, self-talk plays an important role in giving an influence on thought. Self-talk is what people talk to themselves before, during, and after particular situations [3]. Self-talk needs to be managed by a counselor to perform his/her professional activities. It is because self-talk influences an individual's health condition [4], enhances career and individual professional career success [5], and increases happiness [6]. Self-talk is divided into two types, i.e. negative self-talk and coping self-talk [3].

Self-talk is a conscious effort by rearranging the subconscious using self-referential statements[6]. Through self-talk, it is possible for one to reorganize unsupportive thoughts, causing positive thoughts through self-talk can occur. Self-talk influences behavior influencing changes in one's success and failure. The skill to use self-talk is needed in activity areas that require full concentration and clarity of thought under stressful condition[6].

Negative self-talk may give some impacts on the counseling process [7], such as anxiety. Whereas, [8] states that coping self-talk helps individuals to calm themselves down, view better goals, and train themselves to adjust communication with others. Based on the research results of [7] and [8], negative self-talk needs to be avoided, whereas coping self-talk needs to be promoted. To promote coping self-talk, blended learning is one of the available alternative approaches [9]. The use of blended learning is based on the development of the industrial revolution era 4.0 which requires counselors to shift their counseling and guidance service activities from face-to-face counseling services to online-based counseling services by means of telephone, video, cybertherapy, e-mail, and text messaging [10].

Needs identification results on 141 school counselors from five cities in East Java reported that only about $24 \%$ of the counselors understood the term blended learning. It meant that the understanding of blended learning still needed to be promoted to most counselors. In reality, most counselors (aged between 25 to 45 years) already had technology literacy, $73 \%$ of the counselors had work period between 6 to more than 21 years which was actually sufficient to learn about blended learning, most schools $(82 \%)$ in which the counselors worked had a counseling 
room as an important facility for blended learning in Guidance and Counseling services [11]. In addition, one counselor had to provide counseling services for 234 students. It meant that the number of students who must be assisted was abundant. Thus, the counselors need online media, such as blended learning, in Guidance and Counseling services. Furthermore, only an average of 337 students attended face-to-face counseling services per semester. It was only $12 \%$ from 2971 students as the respondents. These results showed that Guidance and Counseling services need new innovations, one of which is through blended learning. Thus, the question posed in this research is how to develop counselors' coping self-talk skill through blended learning to improve professional competence.

\section{METHODS}

School counselors ( 25 people) from 5 cities in East Java were directly involved as participants in a limited field trial. The research method used was one group pre-post test design with a quantitative approach. The sample in the research was random sampling from the counselors in 5 cities, i.e. Malang, Sumenep, Madiun, Jember, and Tulung Agung. Data were analyzed using a non-parametric statistical hypothesis test (Wilcoxon test). Data collection utilized the counselor coping self-talk inventory which was developed based on the coping self-talk indicators, i.e. affirming selftalk, coaching self-talk, and calming self-talk. The counselors as participants worked on a series of pre-tests about the accuracy, acceptability, usability, and attractiveness of the product. Then, they followed the training. Finally, the counselors worked on the post-tests.

Coping self-talk dimensions encountered by school counselors are calming self-talk, coaching self-talk, and affirming self-talk [3]. Calming self-talk is counselors' skill in managing thought verbalization by attempting to calm counselors' thoughts down. Coaching self-talk is counselors' skill in instructing themselves to perform certain actions when dealing with unpleasant situations. Affirming self-talk is counselors' skill in giving a positive affirmation to themselves.

Coping self-talk training by employing a blended learning method provided a set of training able to improve counselors' skill in understanding how to do coping self-talk appropriately. The training was conducted by presenting the training materials offline through face-to-face meetings. In addition, the online material presentation was conducted using videos and the use of a training website at www.blendedlearning.um.ac.id which enabled the counselors to download the training materials and upload their assignments during training. The counselors as the training participants also involved in a discussion regarding self-talk through counseling process practice activity. At the end of the training session, the counselors dealt with real counselee they have never been known. Thus, it encouraged the counselors to perform self-talk directly and it trained how they should do coping self-talk.

\section{RESULTS AND DISCUSSION}

This results and discussion part begins by presenting the t-test results before and after coping self-talk treatment. The results are presented in Table 1.
Table 1. Results of Pretest and Posttest

\begin{tabular}{|c|c|c|c|c|c|c|c|c|c|}
\hline \multirow{2}{*}{\multicolumn{2}{|c|}{ Paired Samples Statistica }} & \multicolumn{8}{|c|}{ Summary of Analysis Results } \\
\hline & & Mean & $\mathrm{N}$ & $\begin{array}{l}\text { Std. } \\
\text { Dev }\end{array}$ & Pos-pre & $t$ & df & sig & Info \\
\hline \multirow[t]{2}{*}{ Pair 1} & \begin{tabular}{|l|} 
Total pretest of self-talk \\
\end{tabular} & 98.31 & $\frac{29}{29}$ & 17.78 & & 2.12 & 28 & 0.04 & $\begin{array}{c}\text { Significantly } \\
\text { increase }\end{array}$ \\
\hline & \begin{tabular}{|l|} 
Total posttest of self-talk \\
Pretest of the negative self-tallk \\
\end{tabular} & 109.72 & 29 & 17.94 & \multirow[b]{2}{*}{-5.00} & \multirow[b]{2}{*}{2.02} & \multirow[b]{2}{*}{28} & \multirow[b]{2}{*}{0.05} & \multirow{2}{*}{$\begin{array}{c}\text { Significantly } \\
\text { decrease }\end{array}$} \\
\hline Pair 2 & \begin{tabular}{|l|l} 
aspect \\
Posttest of the negative self-talk
\end{tabular} & 39.10 & 29 & 9.56 & & & & & \\
\hline \multirow[t]{2}{*}{ Pair 3} & $\begin{array}{l}\text { Pretest of the negative calming } \\
\text { self-talk sub-aspect }\end{array}$ & 14.17 & 29 & 3.19 & \multirow{2}{*}{-1.93} & \multirow{2}{*}{2.28} & \multirow{2}{*}{28} & \multirow{2}{*}{0.03} & \multirow[t]{2}{*}{$\begin{array}{c}\text { Significantly } \\
\text { decrease }\end{array}$} \\
\hline & $\begin{array}{l}\text { Posttest of the negative calming } \\
\text { self-talk sub-aspect }\end{array}$ & 12.24 & 29 & 3.26 & & & & & \\
\hline \multirow[t]{2}{*}{ Pair 4} & $\begin{array}{l}\text { Pretest of the nestative coaching } \\
\text { self-talk shb-aspect }\end{array}$ & 14.62 & 29 & 3.33 & \multirow[b]{2}{*}{-1.21} & \multirow[b]{2}{*}{1.32} & \multirow[b]{2}{*}{28} & \multirow[b]{2}{*}{0.19} & \multirow{2}{*}{$\begin{array}{c}\text { Not significantly } \\
\text { decrease }\end{array}$} \\
\hline & $\begin{array}{l}\text { Postest of the negative } \\
\text { Pogaching self-talk sub-aspect }\end{array}$ & 13.41 & 29 & 3.45 & & & & & \\
\hline \multirow[t]{2}{*}{ Pair 5} & $\begin{array}{l}\text { Pretest of the negative } \\
\text { affirmation self-talk sub-aspect }\end{array}$ & 15.31 & 29 & 2.98 & \multirow{2}{*}{-1.86} & \multirow{2}{*}{2.21} & \multirow{2}{*}{28} & \multirow[t]{2}{*}{0.03} & \multirow[t]{2}{*}{$\begin{array}{c}\text { Significantly } \\
\text { decrease }\end{array}$} \\
\hline & $\begin{array}{l}\text { Posttest of the negative } \\
\text { affirmation self-talk sub-aspect }\end{array}$ & 13.45 & 29 & 3.43 & & & & & \\
\hline \multirow[t]{2}{*}{ Pair 6} & $\begin{array}{l}\text { Pretest of the coping self-talk } \\
\text { aspect }\end{array}$ & 54.21 & 29 & 14.71 & \multirow[b]{2}{*}{16.41} & \multirow[b]{2}{*}{3.02} & \multirow{2}{*}{28} & \multirow{2}{*}{0.00} & \multirow{2}{*}{$\begin{array}{c}\text { Significantly } \\
\text { increase }\end{array}$} \\
\hline & $\begin{array}{l}\text { Postetest of the coping self-talk } \\
\text { aspest }\end{array}$ & 70.62 & 29 & 18.73 & & & & & \\
\hline \multirow[t]{2}{*}{ Pair 7} & $\begin{array}{l}\text { Pretest of the coping calming } \\
\text { self-talk sub-aspect }\end{array}$ & 17.45 & 29 & 5.60 & \multirow[b]{2}{*}{6.62} & & & 0.00 & $\begin{array}{c}\text { Significantly } \\
\text { increase }\end{array}$ \\
\hline & $\begin{array}{l}\text { f the coping calming } \\
\text { ab-aspect }\end{array}$ & 24.07 & 29 & 6.78 & & 3.26 & 28 & & \\
\hline Pair 8 & $\begin{array}{l}\text { Pretest of the coping coaching } \\
\text { self-talk sub-aspect }\end{array}$ & 18.76 & 29 & 4.56 & 431 & 263 & 28 & 0.01 & $\begin{array}{c}\text { Significantly } \\
\text { increase }\end{array}$ \\
\hline & $\begin{array}{l}\text { Posttest of the coping coaching } \\
\text { self-talk gub-aspect }\end{array}$ & 23.07 & 29 & 5.89 & 4.31 & 2.03 & 28 & & \\
\hline Pair 9 & $\begin{array}{l}\text { Pretest of the coping affirmation } \\
\text { self-talk sub-aspect }\end{array}$ & 18.00 & 29 & 5.13 & & & & & $\begin{array}{l}\text { Significantly } \\
\text { increase }\end{array}$ \\
\hline & $\begin{array}{l}\text { Posttest of the coping } \\
\text { affirmation self-talk sub-aspect }\end{array}$ & 23.48 & 29 & 6.39 & 5.48 & 2.92 & 28 & 0.00 & \\
\hline
\end{tabular}

According to Table 1 Self-talk skill in total obtained $\mathrm{t}$-value of 2.125 , sig of $0.04<0.05$, and the difference in means of 11.41. It means there was a significant difference in counselors' self-talk skill before and after training. In other words, counselors' self-talk skill significantly increased by 11.41 points. The negative self-talk aspect obtained a t-value of 2.02, sig of $0.05=0.05$, and the difference in means of -5 . It means there was a significant difference in counselors' self-talk skill on the negative self-talk aspect before and after training. In other words, counselors' negative self-talk skill significantly decreased by 5 points. Each aspect can be explained as follows.

1. The negative calming self-talk sub-aspect obtained a tvalue of 2.28 , sig of $0.03<0.05$, and the difference in means of -1.93. It means there was a significant difference in counselors' self-talk skill on the negative calming self-talk sub-aspect before and after training. In other words, counselors' negative calming self-talk skill significantly decreased by 1.93 points.

2. The negative coaching self-talk sub-aspect obtained a tvalue of 1.32 , sig of $0.19>0.05$, and the difference in means of -1.21. It means there was a significant difference in counselors' self-talk skill on the negative coaching self-talk sub-aspect before and after training. In other words, counselors' negative coaching self-talk skill decreased by 1.21 points.

3. The negative affirmation self-talk sub-aspect obtained a tvalue of 2.21 , sig of $0.03<0.05$, and the difference in means of -1.86 . It means there was a significant difference in counselors' self-talk skill on the negative affirmation self-talk sub-aspect before and after training. In other words, counselors' negative affirmation self-talk skill decreased by 1.86 points.

4. The coping self-talk aspect obtained a t-value of 3.026, sig of $0.00<0.05$, and the difference in means of 16.41 . It means there was a significant difference in counselors' self-talk skill on the coping self-talk aspect before and after training. In other words, counselors' coping self-talk skill increased by 16.41 points.

5. The coping calming self-talk sub-aspect obtained a tvalue of 3.26 , sig of $0.00<0.05$, and the difference in means of 6.62. It means there was a significant difference in counselors' self-talk skill on the coping calming self- 
talk sub-aspect before and after training. In other words, counselors' coping calming self-talk skill increased by 6.62 points.

6. The coping coaching self-talk sub-aspect obtained a tvalue of 2.63 , sig of $0.01<0.05$, and the difference in means of 4.31. It means there was a significant difference in counselors' self-talk skill on the coping coaching selftalk sub-aspect before and after training. In other words, counselors' coping coaching self-talk skill increased by 4.31 points.

7. The coping affirmation self-talk sub-aspect obtained a tvalue of 2.95 , sig of $0.00<0.05$, and the difference in means of 5.48. It means there was a significant difference in counselors' self-talk skill on the coping affirmation self-talk sub-aspect before and after training. In other words, counselors' coping affirmation self-talk skill increased by 5.48 points.

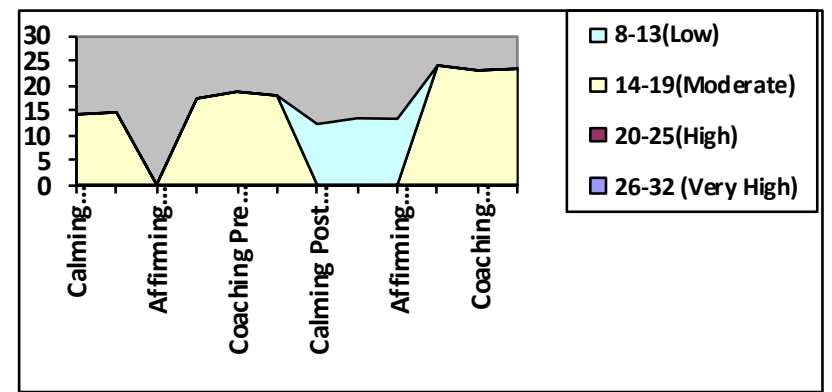

Figure 1. Summary of Descriptive Analysis Results of Pretest and Posttest Average per aspect of Counselor Selftalk Skills

Thus, it can be concluded that both coping self-talk (PST), which consists of calming, coaching, and affirming self-talk, and negative self-talk (NST) were in a quite high position before the counselors participated in the training. After the training, the score of negative self-talk (NST) was decreased into the low position and the score of coping selftalk (PST) was increased from the quite high position to the high position.

Furthermore, it signifies that the self-talk training with a blended learning method has significantly improved counselors' coping self-talk skill when providing counseling services. The improvement can be seen from an increase in coping self-talk skill and a decrease in negative self-talk skill. However, these limited trial results must be further confirmed by conducting a wider scope of research with greater population and sample; not only within East Java scope.

The counseling process is the key point of school counselors when providing guidance and counseling service, though other counseling approaches are available to be taken into account by professional counselors. Professional counselors who conduct counseling services should consider the quality of counseling services in order to accomplish the targeted objective of the counseling process.

Counseling service activities are highly influenced by the way counselors and counselees establish a relationship. Counselors take an important role in the success of the counseling process [12]. Warm and congruent counselors are capable of assisting counselees to be open in expressing what they feel and explaining the problems. It is further beneficial for enabling cooperation between two of them in finding the most possible approach of problemsolving. On the other hand, if counselors are unable to create a positive atmosphere during the service, the counseling service will be hampered.

The success of the counseling process relies on the personality component and interpersonal skills of counselors [13]. Counselors' skill in exhibiting their personality and establishing a therapeutic relationship with counselees plays a prominent role during the counseling process. Counselors' skill in exhibiting their personality is highly affected by the counselors' thoughts when facing counselees. What counselors think the moment they interact with counselees during the counseling process influences the counseling process they perform.

Counselors' skill in using self-talk appropriately becomes one indicator of counselors' performance. In addition to the level of education, gender and experience [14], the steps of the counselor's internal dialogue can be a predictor of counselors' performance. Counselors who have self-leadership will pay attention to self-talk and mental image in improving performance [15].

Negative thoughts and feelings that occurred from self-talk influence the attitude and appearance of counselors [5]. The way counselors dealing with and responding to counselees in the counseling process with negative self-talk could promote fear and unpleasant feeling from counselors. Further, it influences counselors' attitudes toward counselees.

Counselors' thoughts that appear before and during the counseling process influence counselors in having a certain attitude and behavior. Therefore, it influences the counseling relationship. Building positive self-talk enables counselors to lead counselees or direct counselees effectively, while non-functioning self-talk affects creativity negatively [16]. Counselors who have positive self-talk can help counselees to explore problems and find solutions to problems. Counselors who bring up negative self-talk can interfere or hinder the counselors in building a counseling process.

The counselors in this research have not been able to recognize self-talk that has been experienced carefully. It was indicated by the low pre-test results on coping self-talk. Some counselors did not understand self-talk yet and were not aware of the self-talk they experienced. The training on coping self-talk was conducted to provide an understanding to the counselors in recognizing self-talk and controlling selftalk. By performing coping self-talk, the counselors can improve the quality of counseling services and manage selftalk in various situations [3].

Counselors' skill in performing coping self-talk affects the counseling process they do. Counselors who are able to improve affirming self-talk can increase their confidence and focus more on helping counselees. Increased affirming self-talk helps counselors to manage the counseling process. Thus, counselors are able to find their own strengths and experiences to be able to handle the situation and the counseling process.

Evaluation results of the training activities showed that the counselors were not able to recognize the emerging self-talk before participating in the training activities. It can be seen from low initial results. The counselors understood the influence of self-talk in the counseling process through practical activities. The counselors were challenged to do counseling services with new people through counselee 
seeking activities. The counselors gained new experience in recognizing self-talk with a variety of negative self-talk and positive self-talk. Counselors' skill improvement was obtained through the practice of counselors' self-talk management.

Counselors experience doubts, anxiety, and uncontrolled emotions originating from negative self-talk [6]. Counselors experience anxiety in recognizing counselees who are considered "strange" by the counselors' thoughts. This new experience challenges the counselor's skill in managing negative thoughts into positive thoughts. Counselors' feelings that influence counselors' thoughts and actions gradually are expected to be managed appropriately.

Successful self-talk in social talk requires a commitment to oneself [7]. Counselors need a commitment in themselves to use self-talk consistently and manage selftalk. Therefore, counselors' skill in building social relationships through the counseling process can be improved. This commitment will help counselors to manage their self-talk, causing the counseling process can take place effectively.

An effective counseling process involves the abilities, skills, and competencies of professional counselors (PP.19 / 2005). Counselor academic and professional competences are divided into pedagogical competence, personal competence, social competence, and professional competence. Counselor competences can be realized through the counselors' ability and skills in understanding and applying their competences through appropriate guidance and counseling services.

Mastery of technological competence for school counselors becomes an important capability because it is needed in counselors' work [17]. Technological competence needed by counselor which is related to data management, multimedia usage, and web usage becomes a need the counselors have to master. Rapid technological development requires mastery of technological competence that will be needed in counseling activities [18].

Mastery of technological competence is demonstrated by learning implementation that seeks to present online and offline learning in a learning method called blended learning [19]. Blended learning is a teaching method that can meet unique student needs and is effective to be used in learning (Watson, 2008). The research of [9] regarding the use of a blended learning method was conducted to determine the influence of a blended learning method on the development of students' critical thinking. The research of [20] research showed that the use of blended learning can enhance problem-solving learning outcomes and improve student learning capabilities [19]. Blended learning makes it possible to transform the education system and enable higher levels of learning through student-centered competency-based approaches [12].

Coping self-talk training conducted using a blended learning method tried to present interesting training which can be easily performed by the school counselors. The school counselors who already had technology literacy were given training that combined face-to-face activities with online activities. Coping self-talk training using a blended learning method has succeeded in improving pedagogical competence, personal competence, social competence, and professional competence of the counselors. Further research is suggested to consider rational dissemination and wider training for counselors in East Java.
Counselors as professional teachers attempt to adjust to educational development. Classroom activities integrated with online activities in the form of blended learning are recommended for current counselors because they have a positive impact on improving learning in the classroom [21]. Counselors who present learning in a blended learning method can improve students' ability to take lessons appropriate to students' needs.

\section{CONCLUSION}

Counselors' skill in managing self-talk in the counseling process becomes the most important part for counselors in implementing counseling services. By managing self-talk, counselors can manage the negative thoughts that arise during the counseling process and manage them into positive thoughts. Counselors' skill to manage their thoughts will influence the attitude and behavior of counselors to counselees. The training on coping self-talk management using a blended learning method was able to improve coping self-talk skill of participants from 5 cities in East Java. Training in controlling coping self-talk with blended learning-based media (face to face, offline, and online) can improve school counselors' competence. Counselors can realize professionalism in implementing counseling services. Counselors/counseling teachers can use coping self-talk to overcome the thought problems in the counseling process.

\section{REFERENCES}

[1] Widada. Peningkatan Profesional Guru Bimbingan dan Konseling. Seminar Nasional Pendidikan PGSD UMS \& HDPGSDI Wilayah Jawa. ISBN 978-602-70471-2-9. https://publikasiilmiah.ums.ac.id.

[2] Alavi, M., Boujarian, N., \& Ninggal, M. T. (2012). The challenges of high school counselors in work place. Procedia-Social and Behavioral Sciences, 46, 4786-4792.

[3] Jones, Richard, Nelson. 2009. Pengantar Keterampilan Konseling Kata dan Tindakan. Terjemahan Soetjipto, 2012. Yogyakarta: Pustaka Pelajar.

[4] Jemmer, Patrick. Self-Talk: The Spells of Psyhco-chaotic Sorcery (Part 2 of a series of 5). Pandon European Journal of Clinical Hypnosis: 2009 volume 9 - issue 1.

[5] Sara J. White, Using self-talk to enhance career satisfaction and performance, American Journal of Health-System Pharmacy, Volume 65, Issue 6, 15 March 2008, Pages 514-519, https://doi.org/10.2146/ajhp070147.

[6] Helmstetter, S. (1982). What To Say When You Talk To Your Self. New York: Pocket Books.

[7] Geurts, B. (2018). Making Sense of Self Talk. (December 2017), 271285 .

[8] Shafigh, Mitra Rafiee; Rougoushouee, Razieh Abbaszadeh; Yosefian, Samira Tavanaiee. The Effectiveness of Positive Inner Self-Talks Training in Increasing the Happiness of Spouses of Veterans. International Academic Institute for Science and Technology.

[9] Alotaibi, K. N. (2013). The effect of blended learning on developing critical thinking skills. Education Journal, 2(4), 176-185.

[10] Hiebert, Bryan A. 2015, Uhleman, Max,A; Yee, Dong,Yul. Self talk of Counsellor Trainees:A Preliminary Report.(www.researchgate.net). Canadian Journal of Counselling Revue Canadienne de Counseling 1988. Vol. 22:2

[11] Brinthaupt, Thomas M.; Hein, Michael B.; \& Kramer, Tracey E. The Self-Talk Scale: Development, Factor Analysis, and Validation. Journal of Personality Assessment, 91 (1), 82-92, 2009.

[12] Dwiyogo, W.D. 2016. Model Rancangan Pembelajaran Berbasis Blended Learning. Malang: Wineka Media.

[13] Powell, A., Watson, J., Staley, P., Patrick, S., Horn, M., Fetzer, L., ... \& Verma, S. (2015). Blending Learning: The Evolution of Online and Face-to-Face Education from 2008-2015. Promising Practices in Blended and Online Learning Series. International association for $K$ 12 online learning. 
[14] Afrianto. (2018). Being a Professional Teacher in the Era of Industrial Revolution 4 . 0: Opportunities, Challenges and Strategies for Innovative Classroom Practices. 2(1), 1-1.

[15] Neck, C. P., \& Manz, C. C. (1992). Thought self-leadership: The influence of self-talk and mental imagery on performance. Journal of organizational behavior, 13(7), 681-699.

[16] Putri, A. (2017). Pentingnya Kualitas Pribadi Konselor dalam Konseling untuk Membangun Hubungan antar Konselor dan Konseli. JBKI (Jurnal Bimbingan Konseling Indonesia), 1(1), 10 https://doi.org/10.26737/jbki.v1i1.99.

[17] Sabella, R. A., Poynton, T. A., \& Isaacs, M. L. (2010). School counselors perceived importance of counseling technology competencies. Computers in human Behavior, 26(4), 609-617.
[18] Myers, J. E., \& Gibson, D. M. (1999). Technology Competence of Counselor Educators. Eric ED435049. Non Jurnal. https://eric.ed.gov.

[19] Dwiyogo, W. D. (2018). Developing a blended learning-based method for problem-solving in capability learning. Turkish Online Journal of Educational Technology-TOJET, 17(1), 51-61.

[20] Dwiyogo, W. D. 2014. Pengembangan Model Rancangan Pembelajaran Berbasis Blended Learning (PBBL) untuk Meningkatkan Hasil Belajar Pemecahan Masalah. Penelitian Hibah Pascasarjana DP2M. Tahun 2. Malang: LP2M UM.

[21] Corey, Gerald. 2013. Theory and Practice of Counseling and Psychotherapy. Ninth Edition. Belmont: Brooks/Cole Thompson Learning. 